All buildings sit within physical environments, whether made or given. Traditional vernacular architecture was often entirely determined by a response to its physical environment, usually using the means and materials of that physical environment. In a contemporary context, 'High Tech' ceased being rhetorical and became genuinely 'engineered' when it embraced environmental design and finally gave its advanced technology something to do. Rosa Schiano-Phan, in her article 'Environmental Retrofit' (arq 14.3, pp. 139-151), establishes a compelling case for the necessity of addressing the way buildings function in the physical environment. Here, in relation to the need to cut the growing energy demand for conventional mechanical cooling methods, because the conventional electricity grid is finding it increasingly difficult to supply that demand, leading, in cases like the 2003 heatwave, to thousands of deaths. As with EBD, the case for passive cooling - the building envelope doing much of the cooling work that air conditioners would otherwise do - is made by means of empirical data: temperatures, energy consumed, years when consumed, types of buildings doing the consuming, numbers of deaths etc. The closest the text gets to the architectural implications of the strategy emerging from this data - making the building envelope do the work - is in reference to 'geometric applicability', i.e. the effect on the dimensions of a building of inserting new passively cooling walls. It isn't the intention of the article to address these implications but they are implicit nevertheless. A building envelope configured in the interests of environmental performance will influence the design of that envelope. Like EBD, it can in fact determine the design, or it can be one of several considerations driving the design process.

The need to achieve high levels of particular kinds of performance, whether medical or energetic, has been convincingly argued by their champions, but the integration of the empirical and the testable with the intuitive and the conceptual may or may not be susceptible to a conscious procedural 'fix' in practice. We are trying but the effortless integration now achieved by the few may have to wait for the next generation to apply to the many, as architecture students are taught both the empirical and the intuitive, and integrate them internally, as our forebears did. Is Palladio identified as an 'environmental designer'? He certainly was.

SUSANNAH HAGAN Brighton

Susannah Hagan is Professor of Urban Studies at the University of Brighton

\section{The Stirling Turn}

As indicated by Joseph Bedford's article on 'Stirling's Rational Façade' (arq 14.2, pp. 153-164), the second decade of the twenty-first century is becoming something of a James Stirling Renaissance. Exhibitions, essays, conferences and books are marking a renewed critical interest in the wunderkind of post-war British architecture. Among the most noteworthy is an exhibition featuring over 350 of his architectural works to be mounted at Yale in the Fall of 2010 and then again at the Canadian Centre for Architecture in Montreal (where the James Stirling archive is housed) in the Spring of 2012. The show is curated by Anthony Vidler, who is also publishing a book that includes much of the archival material featured in the exhibition, and who organized the symposium 'James Stirling: Architect and Teacher' in May 2009 which brought together academics and Stirling acquaintances to assess his impact and influence on the profession. Articles on Stirling are steadily appearing in architectural journals, including noteworthy contributions by Claire

Zimmerman and Mark Crinson.

The Dutch publication OASE dedicated an entire issue to Stirling in the Fall of 2009. No less than three new books on Stirling (in addition to Vidler's) are currently scheduled for publication-one investigating Stirling's partnership with James Gowan, another revisiting the seminal 'red brick' buildings of the 196os, and another analysing his 'revisionary' techniques for reworking modernism (full disclosure - the last title is my own.)

Why this sudden burst of Stirling interest?

On the one hand, this seems a logical corrective to the appalling lack of Stirling scholarship up to this point. Most contemporary essays begin by pointing out this seeming oversight, while reminding readers of Stirling's unparalleled influence on both academics and practitioners from roughly the mid-1950s until his premature death in 1992. Indeed, a review of the Stirling literature yields a seeming abundance of material which, upon more detailed inspection, reveals little of considered historical or theoretical content. Although nearly all the most important architectural critics and historians - including, but not limited to Colin Rowe, Manfredo Tafuri, Alan Colquhoun, Robert Maxwell, John Summerson, Charles Jencks, Peter Eisenman, Kenneth Frampton, and Anthony Vidler - wrote on Stirling's work, much of this is either hagiographic or anecdotal and none attempted a comprehensive analysis of his considerable oeuvre.

On the other hand, this spike in Stirling interest can be explained at least partially - by the simple fact that enough distance has accumulated to allow for a reading of Stirling's architecture as 'history'. Of course this doesn't account for Stirling's absence relative to other post-war 'third generation' figures like Robert Venturi or Archigram who long ago entered into the historiographical mainstream. We might also consider that enough time has elapsed to allow at least some to forget the disastrous (and highly publicized) mechanical and operational failures of select Stirling buildings (tiles falling from the underside of the Florey Building at Oxford; rain falling inside the glass roof at the History Faculty at Cambridge) which severely damaged his reputation, particularly in his native England.

I would also conjecture that we are seeing more of Stirling these days for the simple reason that post-modernism - with which Stirling is inevitably affiliated - has recently come out of historical hiding and emerged as not only an acceptable but in fact a fertile area of architectural inquiry.

The irony of this resurgence would not have escaped Stirling, who refused the term postmodernism and any affiliation with it. Certainly his best-known works of the 196os, particularly the Leicester Engineering Building of 1959-63, stand out as a culmination of post-war modernism, not postmodernism. When Leicester exploded onto the scene in 1964, Reyner Banham wrote that it was 'reinventing modern architecture' all over again, that it was the first post-war building to approximate the "heroic" work of the 1920 s. $^{1}$ In the 1970s, however, Stirling's 
projects began to incorporate overtly classical references centralized rotundas, columns, and pendentives - and seemed to herald a new sensibility marked by a return to architectural tradition. The Neue Staatsgallerie in Stuttgart (1977-84), it was widely held, embodied Stirling's seeming 'turn' from 'high-tech modernism to a kind of post-modern classicism., ${ }^{2}$ Perhaps the most succinct embodiment of the generally accepted modern/post-modern split in Stirling's architecture is his dual placement in nearly all architectural textbooks: Leicester renders a triumphant conclusion of the 'Modern' section, while Stuttgart floats somewhere toward the beginning of the 'Postmodern' one.

Were there, then, two Stirling 'periods?' Did he shift from a modernist to a post-modernist? And does this go any way toward explaining his mysterious absence from critical analysis? It seems to me that these are the wrong questions to ask, and that the insistence on his postmodern 'turn' is not only detrimental to Stirling scholarship but misses the critical consistency in his architecture. Stirling remained unequivocally and undeniably modern throughout his career. His modernism, however, was always dependent upon, and deeply embedded with, history. Although he incorporated historical sources in his later work (the explicit reference to Schinkel's Altes Museum in the Staatsgalerie rotunda is arguably the most quintessential example), he also incorporated them in his earliest and most seemingly 'modern' projects. Stirling's thesis project of 1950 , a community center, is a reworking of Mies's IIT on Corbusian pilotis; his Churchill College Competition of 1959 refers to medieval castles and fortified cities; and of course, Leicester famously incorporates the jutting lecture halls of Melnikov's Rusakov Worker's Club. In these and countless other examples, it was Stirling's willingness to look to the past as a means to reinvigorate the present that distinguished his architecture. From the beginning, Stirling was unafraid to enter into what he termed a 'dialogue with architectural tradition'.

Understanding that he was manipulating and reconfiguring precedent from his earliest commissions challenges the conventionally held assumption that Stirling's work 'turned' to a more overt use of historical references in the 1970 - i.e. that it became postmodern - and argues instead that his later work, notably Stuttgart, was an evolution of, rather than a break with, his earlier work. Stirling was one of the few architects of his generation to understand that modernism had always been reliant on history. As he was fond of saying, 'There's nothing new in modern architecture'. As someone who refused the term postmodernism, Stirling found that modernism was elastic enough to encapsulate the use of history without betraying its fundamental ideals.

Stirling's architecture was neither avant-garde ex novo invention, nor arriere-garde reiterative traditionalism, but instead a deliberate and daring interplay between the two. He strove to revision, to 'see again', the architecture of the past. For Stirling, the past and the future were always interconnected and mutually dependent. Was that a critical postmodernism? Or an historically-informed modernism? Stirling's architecture challenges the very terms and concepts that
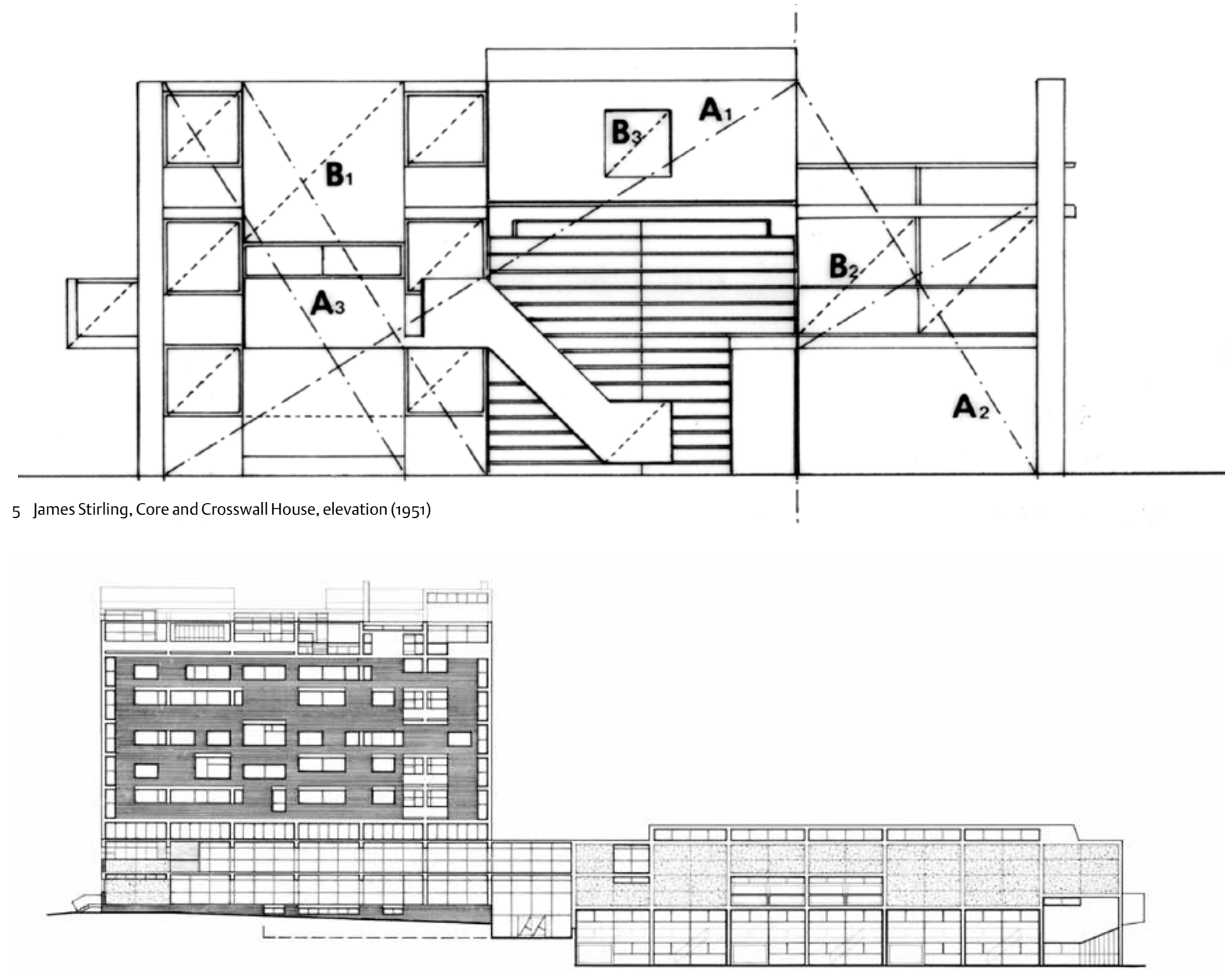

6 James Stirling, Poole Technical College (competition), elevation (1952) 
we use to define it, introducing slippages between the terms modernism and postmodernism, and destabilizing the relationship of the past the present in architecture, between tradition and the new.

Rafael Moneo began his 2005 survey of contemporary architectural practice with Stirling. He wrote: 'Though he is less discussed nowadays, it is obligatory to begin any study of the evolution of contemporary architecture with Stirling. ${ }^{3}$ Indeed, Stirling provides a register of the period during which he practiced; a period which is increasingly being investigated as the foundation of the present era in architecture. Historians, critics and designers alike are re-discovering Stirling as a godfather to a new generation of practitioners who are moving away from the 'high' theory rhetoric of the last few decades by messing around the with 'stuff' of architecture in its raw, corporeal sense (brick, tile, stone, etc.) as well as reengaging the previously taboo postmodernist operations of reference and even (gasp) acknowledging influence.

Claire Zimmerman recently suggested that Stirling's astounding absence from architectural historiography is a result of architectural culture's still deep-seeded fear that his postmodernist operations are, in fact, still at work. ${ }^{4}$ Perhaps, then, we are ready to embrace a more complex understanding of modernism and postmodernism alike, and investigate Stirling's reuse and reinvention of architecture's own history and traditions as a productive and ongoing response to modernism. To do so, we must attempt to 'see again' Stirling's work, to revision our simplistic notion of his modern/postmodern divide and to consider instead how his work reveals fundamental ideas about the role of influence, the possibilities for rethinking precedent, and ultimately for constituting and reconstituting our own disciplinary boundaries.

AMANDA REESER-LAWRENCE

Boston

Amanda Reeser-Lawrence is Assistant Professor in the School of Architecture at Northeastern University.

\section{Note}

1. Reyner Banham, 'The Word in Britain: "Character"', Architectural Forum, August/September, 1964, p. 125 .
2. Martin Filler, 'Cultural Centering,' Architectural Record, September, 1984.

3. Rafael Moneo, Theoretical Anxiety and Design Strategies in the Work of Eight Contemporary Architects (Cambridge MA: MIT Press, 2005), p.3.

4. Claire Zimmerman, 'James Stirling Reassembled', AA Filesi, 56, November, 2007, pp.30-41.

\section{Illustration credits:}

arq gratefully acknowledges : Alvin Boyarsky Archive, London, 1 Brian Ford with Rosa Schiano-

Phan, 4

Rosa Schiano-Phan, 5

Nicole Sully, 2, 3

James Stirling/Michael Wilford fonds Collection Centre Canadien

d'Architecture, 4, 5

Letters for publication should be

sent to:

Adam Sharr

arq

E:adam.sharr@newcastle.ac.uk

The Editors reserve the right to shorten letters 